\title{
PENERAPAN MODEL PEMBELAJARAN KOOPERATIF TIPE JIGSAW UNTUK MENINGKATKAN HASIL BELAJAR FLUIDA PADA SISWA KELAS XI IPA-2 SMA NEGERI 2 BAUBAU
}

\author{
Ummi Salamah \\ Dinas Pendidikan, Pemuda, dan Olahraga Kota Baubau, SMA Negeri 2 Baubau \\ E-mail:ummi.salamah@gmail.com
}

\begin{abstract}
Abstrak
Tujuan penelitian ini adalah untuk mengetahui efektivitas penerapan model pembelajaran kooperatif tipe Jigsaw untuk meningkatkan hasil belajar Fluida pada siswa kelas XI IPA-2 SMA Negeri 2 Baubau. Penelitian ini dilaksanakan di SMA Negeri 2 Baubau, pada bulan Pebruari-April (semester genap tahun pelajaran 2013/2014). Populasi dalam penelitian ini adalah seluruh siswa kelas XI IPA-2 di SMA Negeri 2 Baubau yang terdiri dari 42 siswa. Hasil penelitian menunjukan bahwa model pembelajaran kooperatif tipe Jigsaw dapat meningkatkan hasil belajar materi fluida pada siswa kelas XI IPA-2 pada SMA Negeri 2 Baubau Ketuntasan belajar siswa meningkat dari $0 \%$ (sebelum tindakan) menjadi $57,13 \%$ (siklus I) dan menjadi 78,57\% (siklus II). Rerata nilai siswa meningkat dari 58,60 (sebelum tindakan) menjadi 63,64 (siklus I) dan menjadi 78,57 (siklus II).
\end{abstract}

Kata kunci: fluida, pendekatan, Jigsaw.

\begin{abstract}
The purpose of this study was to determine the effectiveness of the implementation of cooperative learning model Jigsaw to improve learning outcomes Fluid in class XI-2 SMA Negeri 2 Baubau. This research was conducted at SMA Negeri 2 Baubau, in February-April (second semester of academic year 2013/2014). The population in this study were all students of class XI IPA-2 at SMA Negeri 2 Baubau which consists of 42 students. The results showed that cooperative learning model Jigsaw can improve learning outcomes fluid material in class XI-2 at SMA Negeri 2 Baubau Mastery learning students increased from 0\% (prior action) to $57.13 \%$ (first cycle) and to $78,57 \%$ (second cycle). The average number of students increased from 58.60 (before treatment) to 63.64 (first cycle) and becomes 78.57 (second cycle).
\end{abstract}

Keywords: fluid, approach, Jigsaw. 


\section{SANG PENCERAH}

Volume 2, Nomor 2, Agustus 2016, ISSN 2460-5697, Hlm. 59-71

Ummi Salamah: Penerapan Model Pembelajaran Kooperatif Tipe Jigsaw ...

\section{Pendahuluan}

Peningkatan mutu pendidikan, dengan perbaikan mutu proses balajar mengajar, merupakan serangkaian kegiatan terencana, yang akan mendukung keberhasilan pembelajaran. Hasil belajar fisika yang berhasil dicapai siswa dapat dipandang dari dua sisi berbeda yaitu sisi siswa dan sisi guru. Jika dipandang dari sisi siswa, hasil belajar merupakan tingkat perkembangan mental yang lebih baik bila dibandingkan pada saat sebelum belajar. Tingkat perkembangan mental tersebut meliputi perkembangan pada ranah kognitif, afektif, dan psikomotor. Sedangkan dari sisi guru, hasil belajar merupakan saat terselesaikannya bahan pelajaran, dimana proses untuk mencapainya sangat berperan penting.

Berdasarkan hasil ulangan harian I Fisika kelas XI IPA-2 tahun pelajaran 2013/2014 semester 2 hanya mencapai 58,60 (sumber: nilai rata-rata ulangan harian pada materi pokok kesetimbangan benda tegar). jika dibandingkan dengan KKM sekolah sebesar 65, maka dapat dikatakan bahwa nilai tersebut masih berada di bawah standar ketuntasan yang diharapkan. Untuk mendorong motivasi dan keaktifan siswa dalam proses pembelajaran kita perlu mencoba alternatif strategi pembelajaran, diantaranya strategi pembelajaran kooperatif yang kontruktivis guna memberikan kesempatan kepada siswa dalam belajar aktif.

Dewasa ini, banyak tipe dari model pembelajaran kooperatif yang telah diterapkan di kelas-kelas dalam upaya untuk meningkatkan hasil belajar fisika, diantaranya adalah model pembelajaran kooperatif tipe Jigsaw dapat dijadikan alternatif model pembelajaran untuk mengatasi masalah tersebut. Menurut Nur (2005:51), model pembelajaran kooperatif tipe Jigsaw pada dasarnya merupakan sebuah variasi diskusi kelompok dengan ciri khasnya adalah siswa dibagi dalam kelompok Jigsaw dan kelompok ahli. Kelompok ahli sebagai duta kelomok Jigsawnya berdiskusi untuk membahas tugas tertentu karena akan kembali menjelaskan kepada kelompok Jigsaw-nya. Sehingga kelompok ahli mendapat bimbingan dari guru. Artz dan Newman (dalam Huda, 2011: 32), mendefinisikan pembelajaran kooperatif sebagai siswa yang bekerja sama dalam satu tim untuk mengatasi suatu masalah, menyelesaikan sebuah tugas, atau mencapai tujuan bersama. Eggan dan Kauchak (dalam Trianto, 2011:42) mengemukakan bahwa pembelajaran kooperatif merupakan sebuah kelompok strategi pengajaran yang melibatkan siswa bekerja secara berkolaborasi untuk mencapai tujuan bersama.

Arends (dalam Trianto, 2011:47) mengemukakan bahwa ciri-ciri pembelajaran kooperatif adalah (1) Siswa bekerja dalam kelompok secara kooperatif untuk menuntaskan materi belajar; (2) Kelompok dibentuk dari siswa yang mempunyai kemampuan tinggi, sedang, dan rendah; (3) Bila memungkinkan, anggota kelompok berasal dari ras, budaya, suku, jenis kelamin yang beragam; dan (4) Penghargaan lebih berorientasi kepada kelompok daripada individu. Ibrahim (2000: 10) mengemukakan bahwa terdapat enam langkah utama atau tahapan dalam pembelajaran kooperatif. Langkah-langkah itu ditunjukkan pada tabel berikut ini

Tabel 1 Langkah-langkah Pembelajaran Kooperatif

\begin{tabular}{ll}
\hline \multicolumn{1}{c}{ Fase } & \multicolumn{1}{c}{ Tingkah Laku Guru } \\
\hline $\begin{array}{l}\text { Fase }-1 \\
\text { Menyampaikan } \\
\text { tujuan dan } \\
\text { memotivasi siswa }\end{array}$ & $\begin{array}{l}\text { Guru menyampaikan semua } \\
\text { tujuan pelajaran yang ingin } \\
\text { dicapai pada pelajaran } \\
\text { tersebut dan memotivasi } \\
\text { siswa belajar. }\end{array}$ \\
Fase - 2 & Guru menyajikan informasi \\
Menyajikan & dengan jalan demonstrasi \\
informasi & atau lewat bahan bacaan. \\
Fase - 3 & Guru menjelaskan kepada \\
Mengorganisasikan & siswa cara membentuk \\
siswa ke dalam & kelompok belajar dan \\
\hline
\end{tabular}




\section{SANG PENCERAH}

Volume 2, Nomor 2, Agustus 2016, ISSN 2460-5697, Hlm. 59-71

Ummi Salamah: Penerapan Model Pembelajaran Kooperatif Tipe Jigsaw ...

\begin{tabular}{|c|c|}
\hline $\begin{array}{l}\text { kelompok } \\
\text { kooperatif }\end{array}$ & $\begin{array}{l}\text { membantu setiap kelompok } \\
\text { belajar agar melakukan } \\
\text { transisi secara efisien. }\end{array}$ \\
\hline Fase -4 & Guru membimbing \\
\hline Membimbing & kelompok-kelompok belajar \\
\hline $\begin{array}{l}\text { kelompok bekerja } \\
\text { dan belajar }\end{array}$ & $\begin{array}{l}\text { pada saat mereka } \\
\text { mengerjakan tugas mereka. }\end{array}$ \\
\hline & $\begin{array}{l}\text { Guru mengevaluasi hasil } \\
\text { belajar tentang materi yang }\end{array}$ \\
\hline Fase - 5 & telah dipelajari atau masing- \\
\hline Evaluasi & $\begin{array}{l}\text { masing kelompok } \\
\text { mempresentasikan hasil } \\
\text { kerjanya. }\end{array}$ \\
\hline $\begin{array}{l}\text { Fase - } 6 \\
\text { Memberikan } \\
\text { penghargaan }\end{array}$ & $\begin{array}{l}\text { Guru mencari cara-cara } \\
\text { untuk menghargai baik } \\
\text { upaya maupun hasil belajar } \\
\text { individu dan kelompok. }\end{array}$ \\
\hline
\end{tabular}

(Sumber: Ibrahim, dkk. 2000: 10)

Dalam penerapannya dibagi berkelompok dengan 5 atau 6 anggota kelompok belajar heterogen. Materi pembelajaran diberikan kepada siswa dalam bentuk teks. Setiap anggota bertanggung jawab untuk mempelajari bagian tertentu bahan yang diberikan itu (Ibrahim, 2000:21).

Beberapa komponen utama adalah (a) Persiapan. Siswa dikelompokkan secara heterogen, sebanyak 4-6 orang. Setiap kelompok dinamai kelompok Jigsaw (J); (b) Penyajian materi. Materi dibagi-bagi, sehingga setiap anggota bertanggung jawab untuk mempelajari bagian tertentu. Siswa belajar bersama dalam sebuah kelompok, yaitu "Counterpart Group" (CG) atau "Export Group" (EG) atau kelompok ahli, yang merupakan duta dan andalan dari kelompok Jigsaw asalnya. Setiap siswa CG berdiskusi, dan perlu bimbingan guru; (c) Interaksi kelompok Jigsaw. Selanjutnya, jika pekerjaan kelompok CG sudah siap, setiap anggota team CG kembali ke kelompok Jigsaw dan mengajarkannya kembali kepada temannya dalam kelompok Jigsaw; (d) Pengujian hasil belajar. Masing-masing siswa bertanggung jawab secara individu untuk melakukan yang terbaik sebagai hasil bagi kesuksesan kelompoknya; (e) Skor penilaian. Berdasarkan skor awal, setiap siswa memiliki kesempatan yang sama untuk memberi sumbangan skor maksimal terhadap kelompoknya berdasarkan skor tes yang diperoleh; dan (f) Penghargaan kelompok. Perhitungan skor kelompok dilakukan dengan menjumlahkan masingmasing sumbangan skor individu angggota dalam kelompok dan hasilnya dibagi sesuai dengan jumlah anggota. Kelompok yang tergolong istimewa diberikan hadiah penghargaan.

Winkel (1984: 3) memberikan rumusan tentang belajar, yaitu belajar pada manusia merupakan suatu proses psikis yang berlangsung dalam interaksi aktif subjek akan lingkungannya yang menghasilkan perubahan-perubahan dalam pengetahuan, pemahaman, keterampilan serta nilai dan sikap yang bersifat menetap atau konstan. Perubahan-perubahan itu dapat berupa sesuatu yang baru yang segera nampak dalam perilakunya, mungkin juga perubahan hanya berupa penyempurnaan tentang hal yang sudah dipelajari. Berdasarkan teori Taksonomi Bloom, hasil belajar dalam rangka studi dicapai melalui tiga kategori ranah, yaitu kognitif, afektif, dan psikomotorik. Berdasarkan beberapa pendapat ahli, maka dapat disimpulkan bahwa hasil belajar fisika adalah tingkat keberhasilan siswa dalam hal penguasaan pelajaran fisika setelah mengikuti proses pembelajaran dan dilihat dengan skor hasil belajar fisika siswa setelah melalui pemberian tes sebagai alat ukur hasil belajar fisika. Berdasarkan uraian di atas, fokus penelitian ini adalah bagaimana meningkatkan hasil belajar Fluida dengan menerapkan model pembelajaran kooperatif tipe Jigsaw pada siswa kelas XI IPA-2 SMA Negeri 2 Baubau?

Tujuan penelitian ini adalah untuk mengetahui efektivitas penerapan model pembelajaran kooperatif tipe Jigsaw untuk meningkatkan hasil belajar Fluida pada siswa kelas XI IPA-2 SMA Negeri 2 Baubau. 


\section{SANG PENCERAH}

Volume 2, Nomor 2, Agustus 2016, ISSN 2460-5697, Hlm. 59-71

Ummi Salamah: Penerapan Model Pembelajaran Kooperatif Tipe Jigsaw ...

\section{Metode Penelitian}

Penelitian ini dilaksanakan di SMA Negeri 2 Baubau, pada bulan PebruariApril (semester genap tahun pelajaran 2013/2014). Populasi dalam penelitian ini adalah seluruh siswa kelas XI IPA-2 di SMA Negeri 2 Baubau yang terdiri dari 42 siswa.

Metode penelitian yang digunakan adalah metode deskriptif dan metode inferensial. Instrumen yang digunakan dalam penelitian ini adalah skenario pembelajaran, lembar observasi dan tes hasil belajar.

\section{Desain Penelitian}

Penelitian Tindakan Kelas (PTK) merupakan proses pengkajian melalui sistem bersiklus dari berbagai kegiatan pembelajaran. Dalam penelitian ini pelaksanaan tindakan kelas dilaksanakan 2 siklus. Kegiatan setiap siklus, meliputi (1) perencanaan; (2) pelaksanaan tindakan; (3) observsi; (4) evaluasi; dan (5) refleksi. Tahapan pelaksanaan dalam proses pembelajaran di kelas, perhatikan tabel berikut.

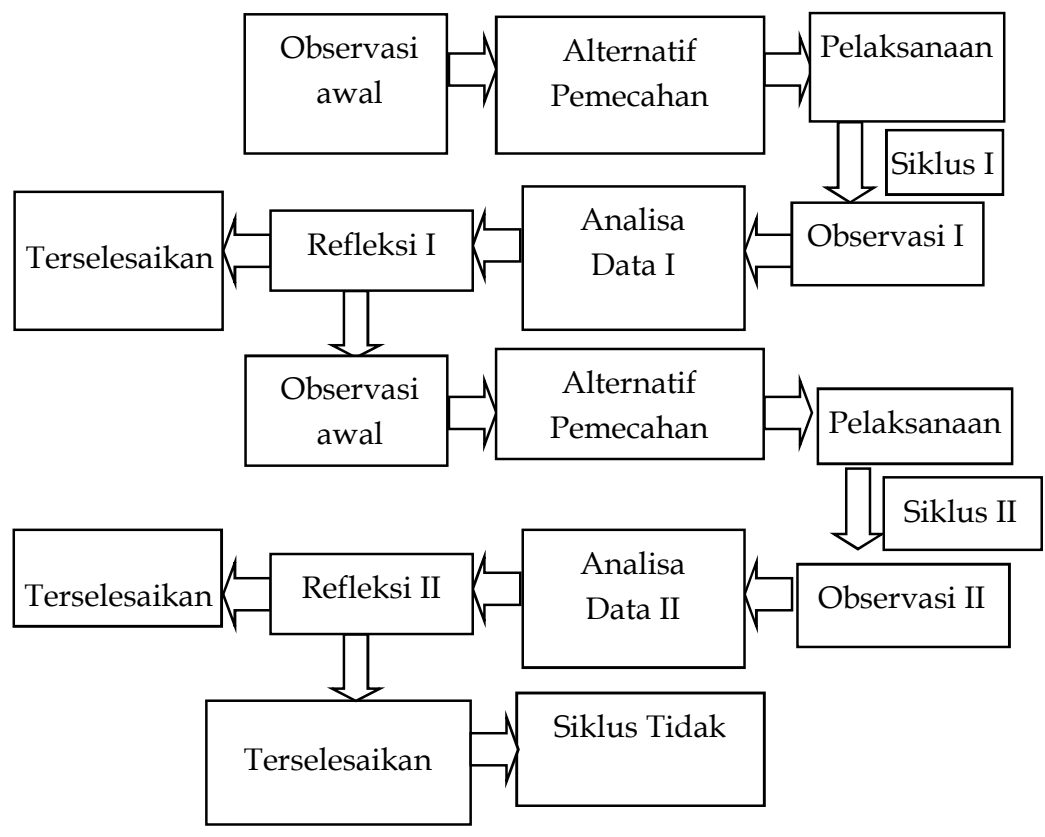

Gambar 1 Rancangan dan Model Penelitian Tindakan Kelas (PTK) (Tim Proyek PGSM, 1999: 27)
Tiap faktor yang diteliti disesuaikan dengan siklus perubahan yang dicapai pada faktor-faktor yang diselidiki. Untuk memantau pelaksanaan tindakan pada proses pembelajaran di kelas, maka dilakukan observasi terhadap aktivitas guru dan aktivitas siswa pada setiap siklus dan yang melakukan observasi adalah teman sejawat guru mata pelajaran fisika (observer) dengan prosedur pelaksanaan penelitian tindakan kelas dijabarkan sebagai berikut:

\section{Siklus I}

a. Permasalahan. Pada awalnya guru merasakan adanya masalah yang berkaitan dengan praktik pembelajaran berdasarkan hasil belajar siswa pada materi sebelumnya, lalu guru sebagai peneliti mengidentifikasi masalah dan menganalisisnya. Selanjutnya merumuskan masalah secara spesifik guna memudahkan pemecahannya;

b. Alternatif pemecahan, yaitu guru menentukan kompetensi dasar dan indikator pembelajaran dari materi pokok Fluida; membuat RPP pertemuan ke-1: Tekanan Hidrostatik dan hukum Pascal dan RPP pertemuan ke-2: Hukum Archimedes serta mempersiapkan sarana pendukung di kelas; mengembangkan dan melengkapi media pembelajaran yang diperlukan selama pembelajaran; membuat lembar observasi aktivitas siswa dan lembar observasi aktivitas guru selama pembelajaran; membuat soal evaluasi untuk melihat hasil belajar siswa setiap akhir siklus dan hasil belajar siswa setelah proses pembelajaran dengan penerapan model pembelajaran kooperatif tipe Jigsaw.

c. Pelaksanaan tindakan, melaksanakan pembelajaran sesuai RPP pada pertemuan 1 dan 2. Dalam pelaksanaannya guru ditemani teman 


\section{SANG PENCERAH}

Volume 2, Nomor 2, Agustus 2016, ISSN 2460-5697, Hlm. 59-71

\section{Ummi Salamah: Penerapan Model Pembelajaran Kooperatif Tipe Jigsaw ...}

sejawat (observer) sebagai pengamat terhadap aktivitas guru dan siswa selama pelaksanaan pembelajaran.

d. Observasi dan evaluasi. Pengamat mengobservasi pelaksanaan tindakan melalui penerapan model pembelajaran kooperatif tipe Jigsaw apakah sudah sesuai dengan RPP yang telah dibuat sebelumya, dan dilakukan evaluasi daya serap siswa terhadap materi yang telah diajarkan.

e. Analisis data. Hasil observasi dan evaluasi selanjutnya diseleksi, disederhanakan, diorganisasikan untuk memberikan jawaban terhadap tujuan ataupun permasalahan yang akan dipecahkan/diselesaikan.

f. Refleksi. Berdasarkan hasil analisis data, guru mengkaji perubahanperubahan aktivitas siswa dan hasil belajar setiap individu. Hasil dari refleksi itu digunakan untuk mengambil langkah lebih lanjut dalam upaya mencapai tujuan pada siklus berikutnya.

g. Indikator keberhasilan siklus I adalah siswa yang menjadi subjek penelitian telah menunjukkan nilai rata-rata tingkat pencapaian hasil belajar sebesar $\geq 65$ dan secara klasikal menunjukkan nilai rata-rata $\geq 75 \%$.

\section{Siklus II}

a. Permasalahan. Hasil refleksi pada siklus I (aktivitas dan hasil belajar) selanjutnya dijadikan dasar pelaksanaan praktek pembelajaran pada siklus II, lalu guru merumuskan masalah guna memudahkan pemecahannya.

b. Alternatif pemecahan. Kegiatan yang dilakukan pada tahap ini yaitu: (1) Guru menentukan kompetensi dasar dan indikator pembelajaran dari materi pokok Fluida; (2) membuat RPP pertemuan ke-3: tegangan permukaan, kapilaritas, dan viskositas; membuat
RRP pertemuan ke-4: persamaan kontinuitas, asas bernoulli dan penerapannya dalam kehidupan sehari-hari. serta mempersiapkan sarana pendukung di kelas; (3) mengembangkan dan melengkapi media pembelajaran yang diperlukan selama pembelajaran; (4) membuat lembar observasi aktivitas siswa dan lembar observasi aktivitas guru selama pembelajaran; dan (5) membuat soal evaluasi untuk melihat hasil belajar siswa setiap akhir siklus dan hasil belajar siswa setelah proses pembelajaran dengan penerapan model pembelajaran kooperatif tipe Jigsaw.

c. Pelaksanaan tindakan. Melaksanakan pembelajaran sesuai RPP pertemuan 3 dan RPP pertemuan 4. Guru dan teman sejawat (observer) sebagai pengamat terhadap aktivitas guru dan siswa selama pelaksanaan pembelajaran.

d. Observasi dan evaluasi. Pengamat mengobservasi pelaksanaan tindakan melalui penerapan model pembelajaran kooperatif tipe Jigsaw apakah sudah sesuai dengan RPP yang telah dibuat sebelumya, dan dilakukan evaluasi daya serap siswa terhadap materi yang telah diajarkan.

e. Analisis data. Hasil observasi dan evaluasi selanjutnya diseleksi, disederhanakan, diorganisasikan untuk memberikan jawaban terhadap tujuan ataupun permasalahan yang akan dipecahkan/diselesaikan.

f. Refleksi. Berdasarkan hasil analisis data, guru mengkaji perubahanperubahan aktivitas siswa dan hasil belajar setiap individu. Hasil dari refleksi itu digunakan untuk mengambil langkah lebih lanjut dalam upaya mencapai tujuan pada siklus berikutnya. 


\section{SANG PENCERAH}

Volume 2, Nomor 2, Agustus 2016, ISSN 2460-5697, Hlm. 59-71

\section{Ummi Salamah: Penerapan Model Pembelajaran Kooperatif Tipe Jigsaw ...}

g. Indikator keberhasilan siklus II adalah nilai rata-rata tingkat pencapaian hasil belajar sebesar $\geq 65$ dan secara klasikal menunjukkan nilai rata-rata $\geq$ $75 \%$.

\section{Alat Pengumpulan Data}

Sumber data penelitian ini adalah seluruh siswa kelas XI IPA-2. Jenis data yang diperoleh dalam penelitian ini adalah data kualitatif dan data kuantitatif. Data kualitatif diperoleh melalui jurnal dan hasil observasi. Sedangkan data kuantitatif diperoleh dengan alat evaluasi hasil belajar. Teknik pengambilan data penelitian ini adalah data tentang pelaksanaan pembelajaran diambil melalui lembar observasi; data tentang hasil belajar siswa diambil melalui tes hasil belajar siswa; data tentang refleksi diri diambil dengan menggunakan jurnal.

\section{Teknik Analisis Data}

Langkah-langkah dalam menganalisis data tersebut adalah sebagai berikut.

\section{Hasil Belajar Siswa}

a. Mengkonversi skor hasil belajar siswa dalam skala 0 sampai 100 dengan rumus:

$$
N=\frac{S p}{S m} x 100
$$

\section{Keterangan}

$N=$ Nilai yang diperoleh;

$S p=$ Skor yang diperoleh;

$S m=$ Skor maksimal yang diperoleh (Usman, 1993).

b. Menentukan nilai rata-rata hasil belajar siswa dengan rumus:

$$
\bar{x}=\frac{\sum x_{i}}{n}
$$

Keterangan

$$
\begin{aligned}
& \bar{x}=\text { Nilai rata-rata } \\
& \begin{array}{c}
\sum x_{i}=\text { Jumlah nilai hasil belajar siswa, } i \\
\quad=1,2,3, \ldots, n
\end{array} \\
& \mathrm{n}=\text { Jumlah siswa (Sudjana, 1996) }
\end{aligned}
$$

Menentukan tingkat pencapaian ketuntasan belajar, dengan menggunakan rumus: $\%$ tuntas $=\frac{\sum f i}{n} \times 100 \%$

Keterangan

$\sum f i=$ Jumlah siswa tuntas belajar dan

$n=$ Jumlah siswa secara keseluruhan (Sudjana, 2005).

\section{Pembahasan}

\section{Deskripsi Hasil Penelitian Siklus I}

Siklus pertama dilaksanakan dua kali pertemuan, dilaksanakan dengan tahapan Pertama, perencanaan tindakan, yaitu merencanakan tentang apa yang akan dilakukan pada saat pelaksanaan tindakan sesuai RPP, yang dilengkapi LKS. Kedua, pelaksanaan tindakan yaitu melaksanakan kegiatan pembelajaran:

a. Kegiatan awal: (1) Menyampaikan informasi umum tentang aturan main dalam pembelaran kooperatif tipe Jigsaw; (2) Mengorganisasikan siswa dalam 7 kelompok (J), Selanjutnya masingmasing dari kelompok Jigsaw (J) mengirim satu anggotanya untuk belajar bersama dalam sebuah kelompok (CG), yang dikenal sebagai "Counterpart Group" (CG) atau "Export Group" (EG) atau kelompok ahli. Sehingga terbentuk 6 kelompok ahli, dengan jumlah anggota masing- masing 7 orang. Kelompok ahli atau kelompok wakil atau CG merupakan duta dan andalan dari kelompok Jigsaw asalnya.

b. Kegiatan inti: (1) Membagikan LKS di tiap-tiap kelompok; (2) Menyampaikan tujuan-tujuan pembelajaran;

Menjelaskan pengertian tekanan; (4)

Menentukan tekanan hidrostatik; (5)

Menjelaskan konsep hukum pascal; (6) Menentukan gaya keluaran pada konsep Fluida; (7) Menjelaskan konsep terapung, melayang dan tenggelam; 


\section{SANG PENCERAH}

Volume 2, Nomor 2, Agustus 2016, ISSN 2460-5697, Hlm. 59-71

\section{Ummi Salamah: Penerapan Model Pembelajaran Kooperatif Tipe Jigsaw ...}

Menerapkan hukum archimedes dalam kehidupan sehari-hari; (9) Membimbing siswa yang bekerja dalam kelompok ahli untuk menyelesaikan tugas-tugas sesuai LKS; (10) Setiap siswa CG berdiskusi dan mengklarifikasi bahan pelajaran dan menyusun sebuah rencana bagaimana cara mereka mengajar kepada teman mereka dari kelompok CG yang lain; (11) Selanjutnya, jika pekerjaan kelompok CG sudah siap, setiap anggota team CG kembali ke kelompok Jigsaw mereka atau kelompok asal mereka, dan mengajarkan bagian yang telah dipelajarinya masingmasing kepada temannya dalam kelompok Jigsaw mereka;

Selanjutnya persentasi dari satu atau dua kelompok Jigsaw yang ditunjuk secara acak; (13) Guru bersama siswa membuat kesimpulan tentang materi pelajaran yang telah dipelajari.

c. Kegiatan akhir: (a) Memberikan tes kemajuan hasil belajar; (b) Memberikan penghargaan individu dan kelompok berdasarkan kinerja tim dalam menjawab soal.

Ketiga, observasi, untuk mengamati keterlaksanaan tindakan siklus pertama. Selanjutnya dari hasil pengamatan guru dan observer terhadap kegiatan siswa dalam pelaksanan tindakan siklus pertama, diperoleh informasi bahwa siswa selalu menunjukkan respon positif selama pelaksanaan tindakan antara lain, siswa menyimak dengan baik informasi dan tujuan-tujuan pembelajaran yang disampaikan guru. Siswa mengungkapkan hal yang diketahui tentang materi ajar yang akan dipelajari, siswa menyimak penjelasan guru dan mengorganisasikan diri ke dalam kelompok-kelompok belajar berdasarkan petunjuk guru, siswa membaca petunjuk dalam LKS, siswa mendiskusikan jawaban pertanyaan dalam LKS dengan menggunakan buku pelajaran fisika, siswa berupaya menyelesaikan tugas kelompok, baik itu sebagai kelompok CG maupun dalam kelompok Jigsaw J sebelum batas waktu yang telah ditentukan dan siswa membuat kesimpulan tentang materi pelajaran yang telah dipelajari. Respon positif siswa selama pelaksanaan tindakan tersebut telah berhasil merubah suasana pembelajaran dari suasana membosankan menjadi mengasyikkan dan menyenangkan.

Sedangkan dari hasil pengamatan guru dan observer terhadap kegiatan siswa dalam menyelesaikan tugas individu diperoleh informasi bahwa, siswa selalu menunjukkan respon positif terhadap tugas individu yang diberikan guru. Hal ini terlihat saat siswa mengerjakan atau menyelesaikan tugas individu, antara lain siswa selalu berupaya menyelesaikan tugas individu dengan tenang dan mandiri, walaupun masih ditemukan beberapa siswa masih mengharapkan bantuan dari siswa lain, siswa berupaya menyelesaikan tugas individu sampai batas waktu yang telah ditentukan dan siswa senang dengan penghargaan yang diberikan guru kepada individu dan kelompok berdasarkan kinerjanya dalam menjawab soal. Selanjutnya untuk memeroleh data yang akurat tentang kinerja siswa dalam menjawab soal dapat dilihat dari analisis hasil belajar siklus pertama (terlampir), bahwa ketuntasan belajar mencapai 77,8 persen.

Di samping keberhasilan-keberhasilan yang telah dipaparkan di atas, terdapat pula kelemahan-kelemahan pelaksanaan tindakan siklus pertama. Dari hasil pengamatan guru dan observer terhadap pelaksanaan tindakan siklus pertama, diperoleh informasi tentang kelemahan-kelemahan pelaksanaan tindakan siklus pertama, diantaranya adalah buku pelajaran fisika yang digunakan untuk menyelesaikan tugas kelompok sangat terbatas, dalam menyelesaikan tugas kelompok interaksi antara kelompok dengan anggota kelompok lain sering terjadi dan dalam menyelesaikan tugas kelompok 


\section{SANG PENCERAH}

Volume 2, Nomor 2, Agustus 2016, ISSN 2460-5697, Hlm. 59-71

\section{Ummi Salamah: Penerapan Model Pembelajaran Kooperatif Tipe Jigsaw ...}

cenderung siswa tertentu saja yang terlibat secara aktif memberikan ide atau pendapat.

Berdasarkan deskripsi data di atas maka dapat disimpulkan bahwa pelaksanaan tindakan siklus pertama berhasil mengubah kebiasaan guru dalam mengajar dari kebiasaan mengajar dengan model pembelajaran konvensional menjadi model pembelajaran kooperatif tipe Jigsaw. Perubahan ini memberikan dampak terhadap perubahan atau peningkatan respon positif siswa sehingga suasana pembelajaran dapat berubah dari suasana pembelajaran membosankan menjadi mengasyikkan dan menyenangkan. Selanjutnya perubahan atau peningkatan respon positif siswa tersebut berdampak pula pada kinerja siswa dalam menjawab soal yaitu ketuntasan belajar mencapai 77,8 persen. Keempat, refleksi, dilakukan untuk merefleksikan pelaksanaan tindakan siklus pertama, bahwa pelaksanaan tindakan siklus pertama masih ada beberapa hal yang perlu dilakukan perbaikan-perbaikan, diantaranya dalam menyiapkan buku pelajaran fisika yang akan digunakan dalam pembelajaran, interaksi antara kelompok dengan anggota kelompok lainnya dalam menyelesaikan tugas kelompok dan keterlibatan siswa dalam menyelesaikan tugas kelompok.

\section{Deskripsi Hasil Penelitian Siklus II}

Siklus kedua penelitian tindakan kelas ini dilaksanakan dalam dua kali pertemuan. Siklus kedua penelitian tindakan kelas dilaksanakan dengan tahapan-tahapan sebagai berikut. Pertama, perencanaan tindakan, yaitu merencanakan apa yang akan dilaksanakan pada siklus kedua dengan memperhatikan hasil refleksi penelitian tindakan kelas pada siklus pertama, antara lain menyiapkan buku pelajaran fisika yang akan digunakanan dalam pembelajaran, mengarahkan kelompok agar dalam menyelesaikan tugas kelompok membatasi diri dalam berinteraksi dengan anggota kelompok lain, mengarahkan kelompok agar dalam menyelesaikan tugasnya semua anggota kelompok terlibat secara aktif untuk memberikan ide atau pendapat.

Kedua, pelaksanaan tindakan, yaitu melaksanakan kegiatan pembelajaran dengan langkah-langkah sebagai berikut.

a. Kegiatan awal: (1) Menyampaikan informasi umum tentang aturan main dalam pembelaran kooperatif tipe Jigsaw; (2) Mengorganisasikan siswa ke dalam kelompok-kelompok kecil yang beranggotan 6 orang dengan mempertimbangkan kemampuan akademik, ras, budaya, dan status sosial. Sehingga terdapat 7 kelompok dan setiap kelompok dinamai kelompok Jigsaw (J), yang telah dibentuk pada pertemuan sebelumnya; (3) Selanjutnya masingmasing dari kelompok Jigsaw (J) mengirim satu anggotanya untuk belajar bersama dalam sebuah kelompok, yang dikenal sebagai "Counterpart Group" (CG) atau "Export Group" (EG) atau kelompok ahli. Sehingga terbentuk 6 kelompok ahli, dengan jumlah anggota masing- masing 7 orang. Kelompok ahli atau kelompok wakil atau CG merupakan duta dan andalan dari kelompok Jigsaw asalnya.

b. Kegiatan Inti

1) Pertemuan Pertama dalam Siklus Kedua

Dalam kegiatan ini berlangsung pengelolaan sintaks penyajian materi dan interaksi kelompok Jigsaw, sebagai berikut: (a) Membagikan LKS di tiap-tiap kelompok; (b) Menyampaikan tujuan-tujuan pembelajaran yang hendak dicapai dalam pertemuan ini; (c) Menjelaskan konsep tegangan permukaan, kapilaritas, dan viskositas; (d) Menentukan kenaikan/penurunan zat cair pada peristiwa kapilaritas; (e) Menentukan tegangan permukaan; (f) Menentukan viskositas zat cair dan koefisien viskositas zat cair; (g) 


\section{SANG PENCERAH}

Volume 2, Nomor 2, Agustus 2016, ISSN 2460-5697, Hlm. 59-71

Ummi Salamah: Penerapan Model Pembelajaran Kooperatif Tipe Jigsaw ...

Membimbing siswa yang bekerja dalam kelompok ahli untuk menyelesaikan tugas-tugas sebagai berikut: Mengarahkan kelompok untuk membaca petunjuk dalam LKS; Setiap siswa CG berdiskusi dan mengklarifikasi bahan pelajaran dan menyusun sebuah rencana bagaimana cara mereka mengajar kepada teman mereka dari kelompok CG yang lain; Selanjutnya, jika pekerjaan kelompok CG sudah siap, setiap anggota team CG kembali ke kelompok Jigsaw mereka atau kelompok asal mereka, dan mengajarkan bagian yang telah dipelajarinya masing-masing kepada temannya dalam kelompok Jigsaw mereka.; Selanjutnya persentasi dari satu atau dua kelompok Jigsaw yang ditunjuk secara acak; Guru bersama siswa membuat kesimpulan tentang materi pelajaran yang telah dipelajari.

2) Pertemuan Kedua dalam Siklus Kedua Dalam kegiatan ini berlangsung pengelolaan sintaks penyajian materi dan interaksi kelompok Jigsaw, sebagai berikut (a) Membagikan LKS di tiap-tiap kelompok; (b) Menyampaikan tujuan-tujuan pembelajaran; (c) Menjelaskan konsep asas kontinuitas dan asas bernoulli; (d) Menentukan kecepatan air pada kasus kontinuitas; (e) Menetukan debit air yang mengalir Menentukan kecepatan air jatuh pada tangki bocor; (f) Menentukan jarak jatuhnya air pada tangki bocor; (g) Menentuakan kecepatan aliran zat cair pada venturimeter; (h) Menentukan gaya angkat pesawat terbang; (i) Membimbing siswa yang bekerja dalam kelompok ahli untuk menyelesaikan tugas-tugas sebagai berikut: Mengarahkan kelompok untuk membaca petunjuk dalam LKS; Setiap siswa CG berdiskusi dan mengklarifikasi bahan pelajaran dan menyusun sebuah rencana bagaimana cara mereka mengajar kepada teman mereka dari kelompok CG yang lain; Selanjutnya, jika pekerjaan kelompok CG sudah siap, setiap anggota team CG kembali ke kelompok Jigsaw mereka atau kelompok asal mereka, dan mengajarkan bagian yang telah dipelajarinya masing-masing kepada temannya dalam kelompok Jigsaw mereka; Selanjutnya persentasi dari satu atau dua kelompok Jigsaw yang ditunjuk secara acak; Guru bersama siswa membuat kesimpulan tentang materi pelajaran yang telah dipelajari.

c. Kegiatan akhir: Memberikan tes kemajuan hasil belajar; Memberikan penghargaan individu dan kelompok berdasarkan kinerja tim dalam menjawab soal.

Ketiga, observasi, dilakukan untuk mengamati keterlaksanaan tindakan siklus kedua. Dari hasil pengamatan observer terhadap tindakan guru dalam pembelajaran siklus kedua, diperoleh informasi bahwa, tindakan guru dalam pembelajaran telah dilaksanakan sesuai dengan apa yang telah direncanakan dalam rencana pelaksanaan pembelajaran. Pelaksanaan tindakan siklus kedua, semakin membiasakan guru dalam mengajar dengan strategi kooperatif tipe Jigsaw. Mengajar dengan strategi pembelajaran ini, bagi guru bukan lagi suatu beban karena merupakan pengulangan dari siklus pertama.

Selanjutnya dari hasil pengamatan guru dan observer terhadap kegiatan siswa dalam pelaksanaan tindakan siklus kedua, diperoleh informasi bahwa kegiatan siswa dalam pelaksanaan tindakan siklus kedua merupakan pengulangan dari kegiatannya pada siklus pertama. Karena siswa mengulang kegiatan yang disenanginya maka respon positif siswa dalam pembelajaran yang nampak pada siklus 


\section{SANG PENCERAH}

Volume 2, Nomor 2, Agustus 2016, ISSN 2460-5697, Hlm. 59-71

\section{Ummi Salamah: Penerapan Model Pembelajaran Kooperatif Tipe Jigsaw ...}

pertama sudah cukup baik maka pada siklus kedua menjadi relatif lebih baik lagi. Menyangkut beberapa hal yang belum baik pada siklus pertama maka pada siklus kedua kelihatannya sudah cukup baik, antara lain siswa senang menyelesaikan tugas kelompok dengan membaca buku pelajaran matematika yang telah mereka siapkan, tanpa bergantian dengan teman satu timnya, siswa senang menyelesaikan tugas kelompok dengan tanpa berinteraksi dengan anggota kelompok lain, siswa sudah banyak yang aktif meberikan ide atau pendapat untuk menyelesaikan tugas kelompok dan siswa aktif membagi ide dan pengetahuanya untuk membantu anggota kelompoknya, walaupun masih ada juga yang pasif. Perubahan atau peningkatan respon positif siswa dalam pembelajaran menjadikan suasana pembelajaran semakin mengasyikkan dan semakin menyenangkan.

Sedangkan hasil pengamatan guru dan observer terhadap kegiatan siswa selama menyelesaikan tugas individu pada siklus kedua, diperoleh informasi bahwa respon positif siswa dalam menyelesaikan tugas individu yang nampak pada siklus pertama sudah cukup baik maka pada siklus kedua menjadi relatif lebih baik lagi, antara lain siswa semakin tenang dalam menyelesaikan tugas individu, siswa semakin cepat dalam menyelesaikan tugas individu dan kinerja siswa dalam menyelesaikan tugas individu atau cara siswa dalam menjawab soal semakin baik. Selanjutnya untuk memperoleh data yang akurat tentang kinerja siswa dalam menjawab soal dapat dilihat pada analisis hasil belajar siklus kedua (terlampir), yaitu ketuntasan belajar mencapai 97,14\%. Di samping keberhasilankeberhasilan yang telah dike-mukakan di atas, dari hasil pengamatan guru dan observer terhadap pelaksanaan tindakan siklus kedua, diperoleh informasi tentang kelemahan pelaksanaan tindakan siklus kedua, yaitu dalam menyelesaikan tugas kelompok, siswa sering mengabaikan ide atau pendapat teman satu timnya.

Berdasarkan deskripsi data di atas maka dapat disimpulkan bahwa pelaksanaan tindakan siklus kedua semakin membiasakan guru dalam mengajar dengan strategi kooperatif tipe Jigsaw. Mengajar dengan strategi pembelajaran ini, bagi guru bukan lagi suatu beban karena merupakan pengulangan dari siklus pertama. Demikian pula bagi siswa, juga mengulang kegiatannya pada siklus pertama. Menyangkut beberapa hal yang belum baik pada siklus pertama maka pada siklus kedua kelihatannya relatif sudah cukup baik. Hal ini semakin meningkatkan respon positif siswa dalam pembelajaran sehingga suasana pembelajaran semakin mengasyikkan dan semakin menyenangkan. Perubahan atau peningkatan respon positif siswa tersebut berdampak pula pada kinerja siswa dalam menjawab soal yaitu ketuntasan belajar mencapai $97,14 \%$.

Keempat, refleksi, dilakukan untuk merefleksikan pelaksanaan tindakan siklus kedua, bahwa pelaksanaan tindakan siklus kedua masih ada hal yang perlu diperbaiki yaitu, perhatian siswa terhadap ide atau pendapat teman satu timnya. Hal ini menuntut kepandaian guru untuk menciptakan suasana pembelajaran yang lebih menyenangkan lagi. Karena ketuntasan belajar mencapai 97,14 persen, maka penelitian ini berakhir padasiklus kedua.

\section{Data Hasil Belajar Siswa}

Data hasil belajar siswa diperoleh dengan menggunakan tes hasil belajar. Berdasarkan analisis deskriptif terdapat hasil belajar siswa pada meteri pokok gerak lurus ditunjukkan dalam bentuk tes siklus I dan siklus II, diperoleh data seperti pada tabel berikut.

Tabel 4 Deskripsi Hasil Belajar Siswa Setiap Siklus 


\section{SANG PENCERAH}

Volume 2, Nomor 2, Agustus 2016, ISSN 2460-5697, Hlm. 59-71

Ummi Salamah: Penerapan Model Pembelajaran Kooperatif Tipe Jigsaw ...

\begin{tabular}{|c|c|c|c|c|c|}
\hline \multirow{2}{*}{ Inisial Siswa } & \multirow{2}{*}{ KKM } & \multicolumn{2}{|c|}{ SIKLUS I } & \multicolumn{2}{|c|}{ SIKLUS II } \\
\hline & & Nilai & Ket & Nilai & Ket \\
\hline APR & 65 & 80 & ST & 90 & ST \\
\hline $\mathrm{AKB}$ & 65 & 66 & ST & 84 & ST \\
\hline ARP & 65 & 60 & BT & 63 & ST \\
\hline $\mathrm{ARH}$ & 65 & 63 & BT & 64 & ST \\
\hline BWP & 65 & 74 & ST & 84 & ST \\
\hline FDM & 65 & 63 & BT & 64 & BT \\
\hline FRY & 65 & 70 & ST & 80 & ST \\
\hline HRM & 65 & 83 & ST & 81 & $\mathrm{ST}$ \\
\hline ILM & 65 & 65 & $\mathrm{ST}$ & 78 & ST \\
\hline LAF & 65 & 63 & BT & 64 & BT \\
\hline LWB & 65 & 70 & ST & 84 & ST \\
\hline MHR & 65 & 62 & BT & 81 & ST \\
\hline MAS & 65 & 70 & ST & 83 & ST \\
\hline MHJ & 65 & 65 & ST & 75 & ST \\
\hline MHD & 65 & 48 & BT & 67 & $\mathrm{ST}$ \\
\hline MKS & 65 & 70 & $\mathrm{ST}$ & 85 & ST \\
\hline RHL & 65 & 63 & BT & 70 & $\mathrm{ST}$ \\
\hline RSL & 65 & 75 & ST & 86 & ST \\
\hline RFS & 65 & 50 & BT & 63 & $\mathrm{BT}$ \\
\hline NJR & 65 & 55 & BT & 64 & $\mathrm{BT}$ \\
\hline SHD & 65 & 58 & BT & 63 & BT \\
\hline SNS & 65 & 75 & ST & 90 & ST \\
\hline SAE & 65 & 60 & $\mathrm{BT}$ & 64 & BT \\
\hline SHT & 65 & 63 & BT & 64 & BT \\
\hline SWR & 65 & 45 & BT & 70 & ST \\
\hline SKM & 65 & 70 & ST & 83 & ST \\
\hline RFT & 65 & 70 & ST & 80 & ST \\
\hline RKM & 65 & 60 & BT & 80 & ST \\
\hline WDR & 65 & 61 & BT & 77 & ST \\
\hline RNS & 65 & 55 & BT & 80 & ST \\
\hline MTA & 65 & 65 & ST & 88 & ST \\
\hline NIS & 65 & 65 & ST & 80 & ST \\
\hline NAW & 65 & 60 & BT & 76 & ST \\
\hline NSM & 65 & 60 & BT & 77 & ST \\
\hline POP & 65 & 62 & BT & 82 & ST \\
\hline STF & 65 & 63 & BT & 73 & ST \\
\hline ST B & 65 & 66 & ST & 89 & ST \\
\hline WDE & 65 & 68 & ST & 82 & ST \\
\hline YAN & 65 & 50 & BT & 75 & ST \\
\hline YNA & 65 & 60 & BT & 70 & ST \\
\hline $\mathrm{ZAB}$ & 65 & 62 & BT & 68 & ST \\
\hline ZAM & 65 & 60 & BT & 75 & ST \\
\hline Jumlah Nilai & & 2673 & & & \\
\hline Rerata Nilai & & 63,64 & & & \\
\hline Nilai Terendah & & 45,0 & & & \\
\hline Nilai Tertinggi & & 83,0 & & & \\
\hline Jumlah ST & & 18 & & & \\
\hline Jumlah BT & & 24 & & & \\
\hline$\%$ ST & & 57,14 & & & \\
\hline$\%$ BT & & 42,86 & & 21 & \\
\hline
\end{tabular}

Penelitian Tindakan Kelas (PTK) siklus pertama adalah merupakan temuan penelitian, bahwa pelaksanaan tindakan siklus pertama berhasil mengubah kebiasaan guru dalam mengajar dari kebiasaan mengajar dengan strategi pembelajaran konvensional menjadi strategi pembelajaran kooperatif tipe Jigsaw. Perubahan ini memberikan dampak terhadap perubahan atau peningkatan respon positif siswa sehingga suasana pembelajaran dapat berubah dari suasana pembelajaran membosankan menjadi mengasyikkan dan menyenangkan. Perubahan atau peningkatan respon positif siswa tersebut berdampak pula pada kinerja siswa dalam menjawab soal yaitu ketuntasan belajar mencapai $57,14 \%$.

Dengan demikian pelaksanaan pembelajaranpun mengacu pada langkahlangkah pembelajaran kooperatif tipe Jigsaw yang disarankan Slavin, yaitu pertama, penyajian kelas; kedua, belajar kelompok; ketiga, tes/kuis; keempat, skor kemajuan individu; kelima, penghargaan kelompok. Langkah-langkah pembelajaran tersebut merubah cara belajar siswa di dalam kelas. Siswa yang selama ini belajar dengan hanya mendengarkan penjelasan guru, mencatat dan sekali-sekali bertanya, ditantang untuk belajar dalam kelompok dan mendiskusikan tugas kelompok. Siswa belajar menurut kebiasaan yang dimilikinya untuk menyelesaikan tugas kelompok. Cara belajar seperti ini mendorong berubahan atau peningkatan respon positif siswa dalam pembelajaran sehingga suasana pembelajaran dapat berubah dari suasana pembelajaran membosankan, menjadi suasana mengasyikkan dan menyenangkan. Perubahan atau peningkatan respon positif siswa tersebut berdampak pula pada kinerja siswa dalam menjawab soal yaitu ketuntasan belajar mencapai 57,14\%.

Pelaksanaan tindakan siklus pertama di atas belum optimal karena masih ditemukan beberapa kelemahan, 


\section{SANG PENCERAH}

Volume 2, Nomor 2, Agustus 2016, ISSN 2460-5697, Hlm. 59-71

\section{Ummi Salamah: Penerapan Model Pembelajaran Kooperatif Tipe Jigsaw ...}

diantaranya adalah buku pelajaran fisika yang digunakan untuk menyelesaikan tugas kelompok sangat terbatas, dalam menyelesaikan tugas kelompok interaksi antara kelompok dengan anggota kelompok lain sering terjadi dan dalam menyelesaikan tugas kelompok cenderung siswa tertentu saja yang terlibat secara aktif memberikan ide atau pendapat. Berdasarkan hasil temuan penelitian dikaitkan dengan pendapat ahli di atas maka dapat dikomparasikan antara kenyataan empirik dengan keharusan teoritik bahwa pelaksanaan tindakan siklus pertama belum optimal dalam hal menyiapkan buku pelajaran fisika yang akan digunakan untuk menyelesaikan tugas kelompok, interaksi antara kelompok dengan anggota kelompok lainnya dalam menyelesaikan tugas kelompok dan keterlibatan siswa dalam menyelesaikan tugas kelompok.

Penelitian Tindakan Kelas (PTK) siklus kedua adalah merupakan temuan penelitian, bahwa pelaksanaan tindakan siklus kedua semakin membiasakan guru dalam mengajar dengan strategi kooperatif tipe Jigsaw. Mengajar dengan strategi pembelajaran ini, bagi guru bukan lagi suatu beban karena merupakan pengulangan dari siklus pertama. Demikian pula bagi siswa, juga mengulang kegiatannya pada siklus pertama. Menyangkut beberapa hal yang belum baik pada siklus pertama maka pada siklus kedua kelihatannya sudah cukup baik. Hal ini semakin meningkatkan respon positif siswa dalam pembelajaran sehingga suasana pembelajaran semakin mengasyikkan dan semakin menyenangkan. Perubahan atau peningkatan respon positif siswa tersebut berdampak pula pada kinerja siswa dalam menjawab soal yaitu ketuntasan belajar mencapai $78,57 \%$.

Selanjutnya keberhasilan-keberhasilan yang dicapai dalam temuan penelitian siklus kedua di atas merupakan peningkatan dari keberhasilan-keberhasilan yang dicapai pada pelaksanaan tindakan siklus pertama.
Keberhasilan-keberhasilan dalam pelaksanaan tindakan siklus kedua dicapai bukan dengan merubah tindakan yang dilaksanakan pada siklus pertama, melainkan melaksanakan ulang tindakan pada siklus pertama. Pelaksanaan tindakan siklus kedua tetap berpedoman pada rencana pelaksanaan pembelajaran (RPP) yang mengacu pada sintaks pembelajaran tipe Jigsaw yang disarankan Slavin. Dengan demikian pelaksanaan tindakan siklus kedua tetap mengacu pada langkah-langkah pembelajaran kooperatif tipe Jigsaw yang disarankan Slavin, yaitu pertama, penyajian kelas; kedua, belajar kelompok; ketiga, tes/kuis; keempat, skor kemajuan individu; kelima, penghargaan kelompok.

Langkah-langkah pembelajaran siklus kedua tersebut merupakan pengulangan dari siklus pertama. Ini semakin mendorong perubahan atau peningkatan respon positif siswa dalam pembelajaran. Perubahan atau peningkatan respon positif siswa dalam pembelajaran menjadikan suasana pembelajaran semakin mengasyikkan dan semakin menyenangkan. Perubahan atau peningkatan respon positif siswa ini berdampak pula pada kinerja siswa dalam menjawab soal yaitu ketuntasa belajar mencapai 78,57\%. Ketuntasan belajar tersebut mencerminkan hasil belajar siswa. Dengan demikian hasil belajar siswa telah mengalami peningkatan yang signifikan sebab ketuntasan belajar mengalami peningkatan dari $57,14 \%$ pada siklus pertama menjadi $78,57 \%$ pada siklus kedua.

Pelaksanaan tindakan siklus kedua di atas belum optimal karena masih ditemukan suatu kelemahan, yaitu dalam menyelesaikan tugas kelompok, siswa sering mengabaikan ide atau pendapat teman satu timnya, karena ketuntasan secara klasikal sudah mencapai di atas $75 \%$ dan rata-rata nilai sudah melampaui KKM yaitu 76,1 sehingga penelitian ini berakhir di siklus kedua. Berdasarkan hasil temuan penelitian dikaitkan dengan pendapat ahli di atas maka 


\section{SANG PENCERAH}

Volume 2, Nomor 2, Agustus 2016, ISSN 2460-5697, Hlm. 59-71

\section{Ummi Salamah: Penerapan Model Pembelajaran Kooperatif Tipe Jigsaw ...}

dapat dikomparasikan antara kenyataan empirik dengan keharusan teoritik bahwa pelaksanaan tindakan siklus kedua belum optimal dalam hal perhatian siswa terhadap ide atau pendapat teman satu timnya.

\section{Simpulan}

Simpulan penelitian ini adalah bahwa model pembelajaran kooperatif tipe Jigsaw dapat meningkatkan hasil belajar materi fluida pada siswa kelas XI IPA-2 pada SMA Negeri 2 Baubau Ketuntasan belajar siswa meningkat dari $0 \%$ (sebelum tindakan) menjadi $57,13 \%$ (siklus I) dan menjadi $78,57 \%$ (siklus II). Rerata nilai siswa meningkat dari 58,60 (sebelum tindakan) menjadi 63,64 (siklus I) dan menjadi 78,57 (siklus II).

\section{Daftar Pustaka}

Huda, M. 2011. Cooperative Learning Metode, Teknik, Struktur dan Model Penerapan. Yogyakarta: Pustaka Pelajar.

Ibrahim, M, dkk. 2000. Pembelajaran Kooperatif. Surabaya: UNESA - University Press.

Lie, Anita. 2002. Cooperative Learning. Jakarta: Grasindo.

Nasar. 2006. Merancang Pembelajaran Aktif dan Kontekstual. Jakarta: Grasindo.

Nur, M. 2005. Strategi-Strategi Belajar. Surabaya: Universitas Negeri Surabaya, University Press.

Sudjana. 2005. Metoda Statistika. Bandung: Tarsito.

Sudjana. 1996. Metode Statistika. Bandung: Tarsito
Sudjana, N. 1989. Tes Sebagai Alat Penilaian Hasil Belajar. Tersedia di http://suluh pendidikan.com/2010/03/tes-sebagaialat-penilaian-hasil.html?m=1.[Diakses tanggal Pebruari 2014]

Tim Proyek PGSM. 1999. Penelitian Tindakan Kelas ( Bahan Penelitian Dosen LPTK dan Guru Sekolah Menengah). Jakarta: Depdikbud.

Trianto. 2011. Model-Model Pembelajaran Inovatif Berorientasi Konstruktivis. Surabaya: Prestasi Pustaka Publisher.

Uno, Hamzah. 1987. Perencanaan Pembelajaran. Jakarta: Bumi Aksara.

Usman, Mohamad. 1995. Menjadi Guru Profesional. Bandung: PT. Remaja Rosdakarya.

Winkel, W. S., 1984. Metode Belajar dan KesulitanKesulitan Belajar. Jakarta : Gramedia. 